\title{
Vaccine (public) diplomacy: legitimacy narratives in the pandemic age
}

\author{
Juan Luis Manfredi-Sánchez ${ }^{1,2}$ (1) \\ Revised: 18 December 2021 / Accepted: 11 January 2022 \\ (c) The Author(s), under exclusive licence to Springer Nature Limited 2022
}

\begin{abstract}
This paper examines how China, United States, the European Union, and Russia deal with the COVID crisis creating a legitimacy narrative to promote their political projects and values. The counter-pandemic measures include the use of public diplomacy tools and the novelty of the vaccine. The results show that presidential overexposure, tweets, and the language of emotion are strong arguments in building an agenda of international relations. This finding highlights the impact of COVID19 on political leadership and public governance. Pandemics contributed to the deinstitutionalisation of public diplomacy. The paper offers a comparative view on the use of strategic narratives for foreign policy objectives. Political communication has performative effects on the international order to the extent to which an action has political consequences.
\end{abstract}

Keywords Public diplomacy $\cdot$ Strategic narratives $\cdot$ Vaccine $\cdot$ Propaganda

\section{Introduction}

The pandemic has driven international political communication policy to the service of a new international order (Kahl and Wright 2021). The manner in which the United States, Russia, the EU and China have responded to the crisis is consistent with their political projects on a national and international scale. Such communication has revealed legitimacy narratives connected to current political undertakings such as the following: American neo-isolationism, Chinese efficiency and competitiveness, and differences between the European model and the aspirations of Russian geopolitics. Global public health action is an incentive for regionalised cooperation under the management of one of the big four. Counter-pandemic measures have had an influence on granting significant importance to certain concepts: global health system (Kornprobst and Strobl 2021), freedom and securitisation (Cull 2021; Kirk and McDonald 2021), international economy (Gereffi 2020), science and leadership (Henley and Ainge Roy 2020), or even IR theories (Davies and Wenham 2020).

Juan Luis Manfredi-Sánchez

Juan.manfredi@georgetown.edu

1 Department of Journalism and International Studies, University of Castilla-La Mancha, Toledo, Spain

2 BMW Center for German and European Studies, Georgetown University, Washington, DC, USA
Public health has contributed to the salience of public diplomacy issues, which are independent from traditional public diplomacy tools employed by governments and institutions. All the actors involved have instruments for furthering their own interests and adapting a previous health monopoly to the current environment. Be that as it may, health-based 'salience' provides an opportunity to open new spaces for direct dialogue with the citizenry and interaction with other stakeholders. The analysis herein focuses on counter-pandemic measures, which symbolise scientific and economic capabilities. It enables understanding of the international political project and the legitimacy narrative (Price 2003, 2015).

Vaccine (public) diplomacy represents the epitome of world leadership in a scientific and non-military capacity (aid, distribution of biomedical supplies, transport of merchandise and people, support of world supply chains, and real reduction of infection), which are key aspects of soft power. The central definition is stated by Nye's canonical work: 'the ability to affect others and obtain preferred outcomes by attraction and persuasion rather than coercion or payment' (Nye 2021, p. 10). Success depends 'on the minds of the target audiences' (Nye 2021, p. 6), so it cannot be exercised alone. According to Bakalov (2019), soft power means targeting foreign audiences; extended time horizon; and strong civil society ties. Vaccine is a tool, a resource sometimes tangible (medical supplies, hospitals, surgical equipment, PPEs, or technological support), sometimes 
intangible (prestige in science results, quality perception), so vaccine includes 'power over nature as well as over other people', key driver in Nye's perspective (2021, p. 1). Vaccine is a new tour de force in a concept that reshaped the way power is understood (Winkler 2020).

Current media ecosystem spreads the messages through a daily presence on all digital devices. This has an impact on audiences, who can now choose selective exposure (Hayden 2012). This has enabled the expansion of legitimacy narratives in the race to legitimise policies and connect with audiences. Donations in the form of money, medical supplies, and vaccines underpin the message. The narratives include elements of disinformation and propaganda, whether from public institutions or from renowned, high-profile, supporting actors. The 'wolf warrior' diplomats represent an innovation in the practice of public diplomacy, with direct messages and political appraisal of the behaviour of other countries (Brandt and Schafer 2020; Huang 2021). This practice deinstitutionalises the message and seeks to delegitimise certain actions or statements.

The present study is structured as follows. Firstly, the strategic narrative is analysed as a theoretical frame of reference for understanding global developments. Political actors respond according to their political projects, conception of the international system, or aspirations. Political communication activity shapes legitimacy narratives. Secondly, the study analyses the actions of the USA, Russia, China, and the EU, as well as the communicative attributes that have been promoted in line with (vaccine) public diplomacy. This study offers an analysis that is descriptive as well as analytical regarding the activities, functions, norms, and values conveyed by the catalogue of measures that each country has promoted with the greatest interest. Finally, the article concludes with a theoretical contribution regarding the legitimacy narratives updated for the post-COVID-19 situation, which have already been foreseen as anti-diplomatic practices or impulses (Cooper 2019). It expands the focus of the deglobalisation era into worldwide public health, an area of research that will be prominent in the study of public diplomacy.

\section{Strategic narratives in the post-COVID-19 world}

\section{Legitimacy narratives}

Strategic narratives provide a set of tools for understanding the world order and political agenda: 'Strategic narrative is soft power in the twenty-first century' (Roselle et al. 2014, p. 71). The reformulation of international relations in the post-COVID-19 world will depend to a great extent on 'whose story wins' (Ronfeldt and Arquilla 2020). Advances in production and distribution of the vaccine provide an opportunity to analyse how power is projected and how it influences geographical areas with the combination of economic aid and the delivery of medical supplies. The narrative serves national interests by supporting the role that each country plays, in addition to their aspired role in the international system. Indeed, each vaccine responds to a geographical structure of sales and distribution in accordance with the priorities of foreign policy (Malacalza and Fagaburu 2021).

Strategic narratives examine three levels of communicative measures. The first is the world structure and the role deployed within. Countries explain the role played by their cultural expression in global civilisation and the power wielded by their political systems (Frankopan 2018). Furthermore, the condition of legitimacy has a strong component of local public opinion, or in other words, the reinforcement of internal leadership. Being recognised internationally as the leader transmits a message to the local audience, regardless of the degree of knowledge or interest in international matters.

The second level assesses identity. Social epistemology is constructed through historical legitimacy, the memory of the past, and values (Ociepka 2018; Manor and Pamment 2021). It is not about a rigorous historical analysis nor a lineal argument, but instead is related to the selection of brilliant historical achievements that support global heritage and the rhetoric of international leadership. The perception of having been a net contributor when the public health crisis ends, whether through the provision of medical supplies and services, economic aid, or providing a vaccine, strengthens national self-esteem and local political initiatives. Due to the growth of nationalist and nativist proposals, the pandemic fuels the discourse against multilateral institutions, free scientific inquiry, and other actors of the establishment (Cooper 2019).

The third level involves examining the agenda to explain how political legitimacy is shaped, the set of desirable regulations, or the design of public policy for tackling a problem (Brands 2017). Legitimacy is constructed through effective decisions whereby executive authority displays its power. In the area of public health, previous experience of pandemics (SARS, MERS) creates an institutional and political memory that understands the relevance of control without a counterbalance. A president's character can increase the visibility of a leader, which configures a scene (theatrical or semiotic) to explain the actions. Representational forces include tweets, photographs, press conferences or releases, and appearances by the leader. The ultimate objective is to resolve a public policy issue. The appropriateness of the type of response (mass vaccinations, border closures, video surveillance, monitoring of individual behaviour, school closures) is justified by the results. The narrative commences with the recognition of leadership capability, which 
is achieved by influencing global events through donations, the fight against the pandemic, and economic recovery. Providing aid in the form of supplies, face masks, and medical products is organised as a ceremony of consumption for the media, which distributes the images and photographs as part of the solution. This is a ritual planned by the aid providers and vaccine distributors, with significant participation by political representatives. It is a 'consensual event' by the one who 'exerts power' (Katz and Dayan 2018, p. 149).

These three levels are interconnected in a hybrid system of political communication (Chadwick 2013) and digital diplomacy (Bjola et al. 2019). Media ecology enhances the value of technology as a mechanism for the reception and dissemination of messages, aside from the official channels or the institutionalisation of diplomatic communication. The official spokespersons and journalists compete with other actors for public attention.

Emotion and resentment characterise the conflict and the identity of the other (Seoane 2013). States influence channels and audiences, as well as disinformation and propaganda (Chernobrov and Briant 2020). Real time and the absence of a counterbalance such as the press, legislative power, and multilateral organisations pave the road towards the political culture of post-truth (Crilley 2018) and the antidiplomatic drive (Bødker and Anderson 2019).

Messages of criticism, conspiracy theories, and insults have multiplied. Coined 'infodemic' (The Lancet 2020; Sardarizadeh and Robinson 2020) includes misinformation, manipulation, and abuse of social media (Ferrara et al. 2020). Having transformed information into a weapon delayed the mass vaccination campaign due to mistrust created among the citizenry. Where panic is effective, diplomacy is needed (Hotez 2021).

An analysis of only one of the dimensions of the strategic narrative cannot be performed. It must be carried out in connection with the other two, as they feed back into messages and behaviour. The presidential figure, the political initiative, and the values that a country fosters are intensified.

\section{Research method}

The present study has been carried out using a qualitative research technique to delve into specific events, organisations, and personalities that shape the legitimacy narrative of a country. This configuration is based on acts of communication and governance, and it manifests the process of power creation. Price describes this phenomenon as 'the organized advocacy of 'narratives of legitimacy' as a way to provide moral and consensual bases for modes of governance' (2015, p. 8). The research topic deals with the impact of measures against the COVID-19 pandemic in the field of public diplomacy (Roselle and Spray 2012).
The research question is the following: How have pandemic measures affected the public diplomacy strategy and narrative of the United States, Russia, China, and the European Union? Even more, how has a discourse of legitimacy been created for each government's particular position in relation to the traditional foundations of public diplomacy? The case involves the implementation of counter-pandemic measures and global public health collaboration within the framework of public diplomacy. This 'fuzzy-set' analysis confronts theory with data (Ragin 2000) as shown in previous works (Hussein and Howard 2013).

The working method of this study is narrative analysis (Shively 2013). The research material is derived from official documents, either from primary or secondary sources. Access to sources has been achieved through the global international press (25 pieces published by Associated Press, BBC, Bloomberg, CNN, Euroactiv, The Financial Times, The Guardian, The New York Times, The New Yorker, The Lancet, South China Morning Post, Reuters, The Conversation) and think tanks ( 7 analysis published by Brookings, PIIE, East Asia Forum, ECFR, Chinese State Council). The publication of official statements and figures does not guarantee the veracity of the data, but it helps to understand the legitimacy narrative perspective. The period of analysis was one calendar year, from March 2020 to March 2021, which is a period that reflects policy action on global public health. Nevertheless, narratives must be distinguished from "stories" (Roselle 2010). While the latter use the past to give meaning to the present, narratives project legitimacy into the future. COVID-19 has been a disruptive element that calls for renegotiation of the 'tacit set of rules for how foreign policy actors are to perform in certain speech situations and articulate responses to policy challenges and problems' (Antoniades 2010, p. 1).

The study of diplomacy involves the capability of examining activity in real time, which makes academic studies more dynamic. This advantage makes it possible to explore international current affairs, yet the limitations are significant: tweets and press releases deinstitutionalise procedures, display contradictions, and cannot be evaluated objectively. Such initiatives oppose Price's argument. In his work, this author suggests that states claim, 'legitimate use of information' (2015, p. 4). However, the current dynamic of presidential hyper-leadership could result in such legitimate use being transferred from the state to the president, and a situation could arise in which 'the collection of ideas and narratives are employed by a dominant group or coalition to maintain power' $(2015$, p. 13). 


\section{Vaccine (public) diplomacy under way}

\section{China: effectiveness narrative}

China has leveraged the COVID-19 to construct a narrative that places emphasis on its technological, scientific, and biomedical capability (Lee 2021; Sharp et al. 2021; Kynge and Lockett 2020). After some dithering and suppression of the initial reporting and research, the Chinese government launched a global scientific and medical leadership campaign that involved direct distribution of aid to more than 120 countries. The donation of face masks and other medical supplies and services has reinforced its image as a country capable of managing global crises, despite its low quality (Peel et al. 2020; Sheperd et al. 2020). The issue is the delivery ceremony at airports and seaports with the backing and presence of the embassy. Infrastructure, logistics, and technological development are discourses that reinforce the autonomy that the Belt Road has generated along with the capacity of China to lead a world order without the United States or the European Union.

The narrative is built upon donating and gift-giving. In Latin America, the impact of face mask diplomacy is considerable. The United States is no longer the leader in the area of cooperation and donations. During a virtual meeting that took place in July of 2020, Chinese Foreign Minister Wang Yi guaranteed a loan of one billion dollars to Latin America and Caribbean countries in order for them to gain access to the vaccine (Spinetto and Adghirni 2020; Stott 2020; Xie 2020). The Chinese statement read as follows: 'China's Foreign Minister said that the vaccine developed in his country will be a public benefit of universal access, and that his country will designate a loan of $\$ 1$ billion to support access [to the vaccine] for the nations of the region'. In Europe, Serbian President Aleksander Vučić has declared that 'without China and our Chinese brothers, we would be incapable of doing so'. He also guaranteed the 'centennial and strong-assteel friendship' between Serbia and China (Simić 2020). In Southeast and Central Asia, it is taken for granted that the vaccines will come from China in line with bilateral relations and preferential access to medical goods and services. This competitive advantage nearly rules out other pharmaceutical companies from entering these markets. In Africa, even though the number of healthcare workers, face masks, and protective suits has satisfied local demand, the Chinese have attempted to draw a veil over the racist treatment of African citizens living in China. In Japan, the humanitarian crisis has eased relations at the parliamentary level with mutual acknowledgements ( $\mathrm{Li}$ and McElveen 2020).

The gift-giving narrative is not focused on shared values nor political projects, but instead is oriented towards the resolution of specific issues of funding, medical aid, vaccine distribution, access to $5 \mathrm{G}$ technology, and so on. For countries of the Global South, China represents an alternative that provides rapid access and economic aid. This narrative is attractive for a growing number of countries, which consider that medical aid, investment, loans, and the return to normal life represent an exercise of mutual interest. Political discourse in Serbia and Mexico follows along these lines. During his daily briefing, President López Obrador stated the following: 'We're very grateful to China, the Chinese government, and the President-you remember I had the chance to speak to him on the phone-we asked him for support with medical equipment, and there have been many flights with aid coming from China' (Suarez 2020). In the private sector, John Nkengasong, director of the African Centres for Disease Control and Prevention, stated the following: 'We are extremely pleased and proud of the partnership with the Jack Ma Foundation', after receiving help to test 1 million people. (Associated Press 2020).

With regard to values, the 'Beijing Consensus' is gathering steam, with China investing in countries regardless of the local position on human rights (Ramo 2004). This geopolitical shift revolves around the message that Beijing alone can lead the crisis response without the need for international cooperation, but solely based on its technological supremacy, nor human rights issues. Consensus is an empty descriptor, which allows for generic rhetoric to define the many variants of Chinese foreign policy. This broad-minded attitude highlights a fundamental characteristic: the pragmatic approach towards international relations, which offers each potential partner a specific and customised solution (Chen 2017). Pragmatism builds a narrative of legitimacy through facts. It does not need to model a multilateral governance system in order to be effective.

The implementation of Chinese policy has rested on logistical decisions and the BRI, both of which have reinforced its self-sufficiency discourse. The nationalist response of the EU, the United States, and the United Kingdom has given China greater negotiating power, for it has in fact been capable of sending supplies made in China by way of the infrastructure offered by the Belt and Road Initiative (hereinafter BRI), as well as marking a 'downward spiral' in multilateral cooperation. This strategic narrative combines medical action with trade in accordance with the positioning of China in the new post-COVID-19 structure. In Brazil, access to vaccines for the region of Sao Paulo has caused confrontation between Governor Joao Doria and President Jair Bolsonaro. Doria, who is one of Bolsonaro's political rivals, had promoted direct agreements with the Chinese firm Sinovac, regardless of presidential instructions to stop the medical trials of the drug (Simoes and Liu 2020).

Likewise, massive dissemination on social media of its feat of building a field hospital in just ten days has emphasised its international power based on infrastructure and 
technology. Moreover, China has also resorted to the infrastructure and capital of Jack Ma, the founder of Alibaba, as a kind of entrepreneurial soft power. His consignments of face masks and medical supplies have received the support of ambassadors and social networking sites, with the widespread deployment of institutional symbols (Bially 2005). Ma's popularity is a reflection of China's public and private collaboration strategy founded on infrastructure, logistics, and technological development. In the Latin American region, Ma himself has tweeted diligently regarding the supply of two million face masks, 400,000 tests, 104 ventilators to Latin American countries, 500-plus ventilators distributed to various African countries, as well as the initial 1000 that were sent to the New York public health system. In Asia, the Alibaba Foundation sent 210,000 tests, 36,000 protective suits, and 1.8 million face masks to Nepal, Mongolia, Pakistan, and Afghanistan.

Huawei has offered its satellite network, artificial intelligence, and technology for early diagnosis. The donations include protective gear and masks sent to Spain, Ireland, Zambia, South Africa, and 20 other countries. By contrast, the support of Huawei has led to a fair amount of controversy in Canada, the United States, and the European Union itself, taking into account the association with Huawei's commercial strategy regarding 5G technology. The Tencent Corporation, a regional leader in technological services, pledged 100 million dollars and sent face masks to 15 countries, including the United States.

The creation of the Health Silk Road (健康丝绸之路) combines biomedical leadership with efficient distribution of medications, together with trade and investment in the healthcare industry, as well as standardisation of drug access. Since 2015, Chinese health authorities have promoted a system of cooperation as an alternative to the one that currently exists, including the 'Beijing Communiqué of the Belt and Road Health Cooperation and Health Silk Road' initiative (2017). The initiative was signed by China, the World Health Organization, UNAIDS, and 30 countries. The success of the programme is measured by the capacity of response (Chow-Bing 2020).

The efficiency narrative is reinforced by the quality of the global supply chain, capacity building, and professional training. The control of ports and intermodal connections, in addition to direct access to manufacturing plants of medical supplies, has guaranteed distribution. Participation in this network represents an express contribution of public diplomacy, a 'community of common destiny for mankind' (人 类命运共同体), as stated by Xi Jinping in the World Health Assembly (73rd-November 2020), and in the preliminary documentation of The State Council held in June of 2020). The contribution was kept to a reasonable cost thanks to the use of the BRI facilities.
The pandemic has confirmed the degree of vulnerability of all countries to globalisation, the extent of access to supply chains, the production of medical equipment, and border controls for limiting the movement of people. In the case of China, the fifth plenary session of the Central Committee of China (October 2020) coined the term 'dual circulation' as a model in line with the deglobalisation trend (Zhang 2020). For the domestic audience, it means the development of local demand, the protection of supply chains, and technological autonomy. For the foreign audience, the plan reduces dependency on commodities and exports that respond to nationalism, protectionism and unilateralism. The plan updates the document 'Made in China 2025' which, from a techno-nationalist approach, indicates the need to be a leader in robotics and smart manufacturing, semi-conductor fabrication, self-driving vehicles, artificial intelligence, and industrial biotechnology, with the support of the infrastructure and transport provided by the BRI. Counter-pandemic initiatives serve this end by promoting economic stability and recovery.

Lastly, an assessment of President Xi Jinping should be considered. He appears in the state news media outlet Xinhua as the 'leader who commands the decisive battle', whose deaths are 'martyrs'. The distributed video included slogans such as 'Resolutely winning the people's war' (Lun Tian 2020). His presence is uncommon at ceremonies involving aid delivery, but his profile is based on its management. The Chinese government legitimises its actions, but not with the public presence of President Jinping. Instead, the government appeals to the effectiveness of its own public policies.

In summary, the Chinese position has created a narrative of gift-giving and efficiency in its handling of the pandemic. The combination of generosity in the form of donations, medical supplies, direct aid, and investment, together with positive initiatives on public health issues, offers salient public diplomacy that benefits the Chinese government. This narrative contributes to the legitimacy of the system (the president appears as a problem-solving leader), the expansion of Chinese cooperation (the Health Silk Road), and the promotion of self-interest (vaccine sales).

\section{The United States: neo-isolationism is the message}

The response of the United States to the COVID-19 pandemic has been influenced by its neo-isolationism (Cha 2016; Clarke and Ricketts 2017) during the Trump administration. 'America First' lacks meaning in an interconnected environment with mutual dependencies regarding the production of medical goods and services, especially vaccines. The closure of borders has damaged American industry (Bown 2020), but the narrative has been redirected towards nationalism and exceptionalism. Border closures to limit exports and increased tariffs have a direct effect on the 
functioning of competition, which acts accordingly. More than 150 measures contrary to free trade were approved in 2020. Hence, the reason for the continuation of the Trump administration is justified from the perspective of the narrative of values and identity. These are popular measures for the domestic audience as they include the provision of aid for employment, limitations on the export of medical goods and services that can be used in American territory, and the allocation of resources for social services (Evenett and Fritz 2020). This collection of measures must be viewed within the dynamics of the figure of President Trump himself, who was already in the race for re-election for a second term. They are political communication initiatives that reinforce his electoral framework and the message to his voters. The health crisis serves local interests.

This can be observed in the Trump administration's policy of minimising the problem for weeks, or blaming China for its bad management. The fact that President Trump has set himself up as the 'wartime president' has granted him special decision-making powers and has allowed him to act in a hostile manner towards individuals or media outlets that have cast doubt on his health policies. The 'wartime president' (Smith 2020) authorises militaristic language against 'the invisible enemy' whose effects are 'worse than those of Pearl Harbor, and even worse than the attack on the World Trade Centre' (BBC 2020). The hyper-leadership of executive power is founded on the condition of 'extraordinary events', which is laid down in article II, section 3 of the American Constitution. Under this umbrella, Trump rushed through 165 appointments as being 'necessary' for the management of the pandemic, forcing proceedings.

Trump's hyper-leadership confirms the deinstitutionalisation of diplomatic practice, which has an impact on multilateralism. The disrepute into which the World Health Organization has fallen has led to the withholding of monetary contributions and, above all, to accusations of it being Sinophile. Trump has bandied about the idea of its being a multilateral organisation that mismanages global public

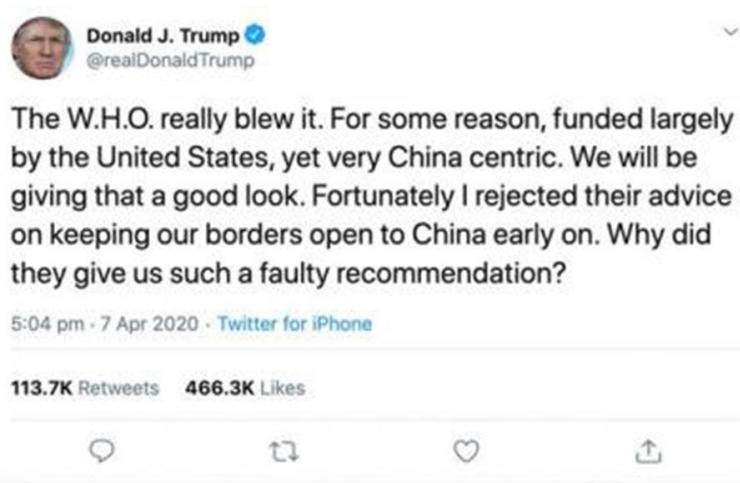

Fig. 1 Trump's comment on the WHO and China assets and claims it is trying to cover up Chinese mismanagement (Fig. 1).

Judd Deere, a spokesperson for the White House, has accused COVAX of malpractice and has said that the United States will not limit its foreign intervention in matters of worldwide public health. Neo-isolationism when confronting COVAX is tagged as follows: "constrained by multilateral organisations influenced by the corrupt World Health Organization and China' (Mason 2020). However, the Trump administration has created Operation Warp Speed aimed at administering the vaccine using federal funds. The Operation is the unilateral response to the WHO absence. Contributing efforts out of the multilateral system hindered the vaccine development as global public good and the global supply cannot be attended. Data show that vaccines under the Operation were allocated to national markets (Duke Global Health Innovation Center 2020).

In practice, the absence of Russia and the United States from the COVAX initiative, which is a two billion dollar donation towards the vaccine plan, has enabled China's financial hegemony. With 95 high-income and 92 lowincome countries, the absence of the United States weakens the narrative of a multilateral order. Furthermore, if Chinese medicine is distributed rapidly among low-income countries, the image of China will be reinforced and multilateral cooperation greatly damaged. Following Joe Biden's victory, it remains to be seen how and under what conditions the United States will join this coalition. In any event, the decision will depend on Congress, above all. However, the possibility exists that the focus on neo-isolationism will delay the effectiveness of any decision until the summer of 2021.

In the international order, the neo-isolationism of the United States is linked to its ongoing dispute with China. The message 'America First' has been reinforced during the crisis. International economic analysis shows a regional trade policy focused on the United States that is removed from global procedures. It is not so much deglobalisation as trade regionalisation, a reshoring of industry and the reduction of energy dependency on the Gulf region. The nationalist rhetoric has coined the term 'decoupling' to mask neoisolationism and to avoid conflict with China.

If the United States abandons its international position, China will broaden its scope of influence in global public health and climate change institutions. This decision has given China the opportunity to occupy spaces of multilateral leadership. As a result, the United States will be seen as uninterested in upholding the rules-based global order, or in supporting its European allies. Following Brexit, the United Kingdom and Europe still have not thrashed out trade agreements and, in the current nationalist political climate, China could offer preferential accords similar to those of the Asia-Pacific Economic Cooperation. This anti-diplomatic drive has led to decisions being taken that are contrary to the 
message of the regional leader of the hemisphere. Exports of medical supplies to the Ibero-American region have been blocked, which has boosted Chinese trade in the region.

With regard to values, Trump's isolationism is supplemented by a xenophobic discourse in the US media. The Trump administration has also continued to implement an increasingly stringent immigration policy. By calling it the 'Chinese virus', the US President has directly associated it with China (Viala-Gaudefroy and Lindaman 2020). Mike Pompeo described the illness as the 'Wuhan virus' and contributed to conspiracy theories by referring to the possibility that it was accidentally released from Wuhan labs and facilities. Right-wing commentators have also suggested that China created the coronavirus. Pundits like Laura Ingraham of Fox News have remarked that social surveillance practices that are being put in place as a result of the pandemic are violating the right to privacy. Well-known anti-vaccination advocates, such as Robert F. Kennedy Jr., have pointed the finger at Bill Gates, who is a proponent of multilateral cooperation and mass vaccinations. Conspiracy theories and paranoia are fuelling these movements contrary to science.

The legitimacy narrative has constructed a discourse of safety and security, and 'America First'. This action has resulted in measures contrary to free trade and control of competitive activity. The exceptional nature of the situation justifies the arbitrariness of the presidential mandate and is in line with other conduct of the Trump administration. In the same period, the appointment of judges for international arbitration has been ignored, and the Paris Agreement on climate change (2015) has been renounced as well. Senator Josh Hawley has called for 'economic sovereignty' (2020), or in other words, the revision of trade agreements signed to date. By taking advantage of the exceptional circumstances caused by the pandemic, these types of measures represent a full-on attack against multilateralism. The withdrawal from the trade institutions of globalisation violates the legal security of the system.

Lastly, the pandemic has affected the electoral race as well. Its continuous presence in press conferences sets the briefing agenda, which is augmented by the systematic publication of tweets justifying the Trump administration's decisions. Attacks against the press, the WHO, the Democrats, and the Chinese government are constant, which polarises the arguments and debates. The anecdote of drinking disinfectant to eliminate the virus reflects a communication technique that favours direct intervention in any serious matter without thoroughness or previous consideration. It is the deinstitutionalisation of medical practice and a discourse contrary to expert knowledge, which maintains that the effectiveness of American public policy depends on the desires of the president and to a lesser extent on scientific decisions. The fact that the president himself suffered from the virus contributes to building the image of a leader who resolves problems.

\section{The European Union: emotionless economic bureaucracy}

The European Union has gone through two discursive phases. The construction of a legitimacy narrative is hampered when there is no coherence between the main actors. The haste and impatience with regard to the health emergency have shown the weaknesses of the European project. The disorder that reigned during the first weeks, including uncoordinated border closures, barriers to the export of products from 'strategic industries' such as pharmaceuticals, and the hindmost attitude of its Member States imbued with the nationalist demon gave the impression that its political project was tottering.

Nevertheless, after the initial shock had passed, the European Commission began to construct a second narrative phase based on extraordinary financial measures. These have included the suspension of fiscal rules, the enabling of public guarantees, the redirection of existing funds and programmes, and the approval of a reconstruction fund. This brings back memories of the post-war Marshall Plan, with an unprecedented increase in the budgetary ceiling. Even though it has lent stability to the situation, it is still in the early days to compare these measures with those implemented after the 2008 financial crisis. Other significant economic measures have affected the European position in the international system and the very ordering of the domestic market (relaxation of import restrictions on medical products and the inter-European donation of face masks and gloves). The slogan 'Stronger Together' has gained renewed importance, far removed from the economic crisis, through the transfer of patients between European hospitals. It is the narrative of the European demos.

The European narrative recognises China as a competitor on the international stage (European Commission 2019). In a public statement issued on 23rd March 2020, EU Common Foreign and Security Policy Chief Josep Borrell admitted that the 'politics of generosity' have been followed by a 'global battle of narratives'. He also identified the Chinese donations with a 'geopolitical component including the struggle for influence' in which 'China is aggressively pushing the message that unlike the USA, it is a responsible and reliable partner' (Borrell 2020). The argument of the High Representative of the European Union considers that medical cooperation pursues strategic gain, whether in terms of providing goods or in the efficiency of the Silk Road infrastructure.

Shortly afterwards, the bulletin EUvsDisinfo, dated April 2020 , associated the aid with undercover operations based on disinformation (surrounding the origin of the virus) and 
conspiracy narratives (the virus being imported by American troops), and even an alleged human origin of the virus. The publication does not represent the official position of the European Union, but is defined as a compilation of information and analysis under the East Stratcom Task Force. The report asserts that the informative actions have fostered an impression of effectiveness in the aid provided by China compared to the inaction of Europe. The statements and bulletins greatly annoyed Chinese leaders, who expressed their anger. Zhang Ming, China's ambassador to the European Union, considered that these official statements were 'political' and were creating distance between the shared solutions aimed at slowing the advance of the pandemic (Peel 2020).

European political leaders have disputed the Chinese narrative. The ministers of foreign affairs for the United Kingdom and France have expressed a certain level of distrust of the effectiveness of China. The lack of transparency in providing data, the expulsion of journalists for reasons of security, and the lack of scientific collaboration have caused distress within European Chancelleries. Angela Merkel has personally encouraged the sharing of research advances to discover the origin of the virus and to find a vaccine (Lau and Wong 2020). The dual discourse of scientific leadership and economic impact aspires to be the framework, or frame, of EU decisions. However, until an effective vaccine has been found, or until the money from benefactors runs out, the European framing of leadership and effectiveness will be less successful than the mass donation of medical supplies.

The narrative of international prestige has been obtained through the Donors Conference, hosted by the European Commission to raise at least 7.5 billion euros. A total of 40 governments responded to the call to gather funds in order to fight the pandemic, specifically focusing on diagnosis, treatment, and a vaccine. It was striking to see the last-minute involvement of China with a message of 'responsibility to the international community', 'social trust and solidarity', and a donation of 30 million dollars. The Donors Conference was a barometer of the hostile narrative of other countries against multilateral institutions. India, Russia, Brazil and the United States have not participated, while France, Italy, Norway and Germany have been proactive in encouraging involvement. The fundraising adds strength to the Access to COVID-19 Tools (ACT) Accelerator, the purpose of which is to speed up multilateralism with a medical orientation coordinated by the World Health Organization (WHO). The message reinforces the value of cooperation through international organisations. The economic dimension has found support in the memorandum of understanding between the WHO and the European Investment Bank (EIB), the financial vehicle that enables the incorporation of private partners. However, these initiatives have not been achieved under a single strategic narrative of an international position.
The COVAX umbrella, which is one of the pillars of the ACT accelerator that defends fair access to a vaccine (a collaboration with the Global Alliance for Vaccines and Immunisations [Gavi] and the Coalition for Epidemic Preparedness Innovations [Cepi]), has not served as an instrument to build a Europe that exports values of solidarity with lowand middle-income countries. The distribution of the first vaccines without this solidarity label has converted the provision of medical products into a pharmaceutical business. In this regard, the Chinese deployment is more efficient. Payment of the vaccines from COVAX funds will enable the purchase of two billion doses, although the distribution is irregular. Some countries will have to wait until 2024 to receive their supply. The need to increase donations and the introduction of 'vaccine bonds' represent an opportunity for the European narrative, once the Next-Generation EU programme has been launched.

In view of the fact that the European Union has been incapable of conveying a unitary message of solidarity or providing a common solution to the crisis, some countries have been less reluctant to accept foreign aid. Italy has shown its gratitude to Russia and China for the medical support it received from them. This is due to social polarisation and the use of diplomacy to reinforce a vision of the world order (Coratella 2020). The Five Star Movement has linked Chinese aid to Italy's support for the BRI, which is consistent with recent opinion polls: $36 \%$ of Italians consider that China should be their top ally outside the European Union, while only $30 \%$ believe it should be the United States. Regarding the conservatives, the Partito Democratio is of the opinion that the European efforts are in line with the social values and structural interests of Italy, with $51 \%$ of conservative voters preferring the United States over China as the country's top non-European partner. With this polarisation, it is the European Union that is losing out: $49 \%$ of Italians are in favour of abandoning the EU, which is $20 \%$ more than in 2018. On social media, Chinese propaganda in Italy is less sophisticated: $46 \%$ of the tweets include the hashtag \#forzaCinaeItalia, and $37 \%$ of those featuring \#grazieCina have been generated by bots (Alkemy Lab 2020). The Italian example clearly shows that the Chinese offensive is capable of countering the influence of Germany and France on trade decisions in the European Union. Thus, the current state of affairs in Italy may lead to the signing of a new treaty within the framework of the BRI. Chinese expansion in Europe would ultimately tip the global balance in favour of the Asia-Pacific region.

The European Union has constructed a legitimacy narrative that revolves around economic recovery and aid to its member states. Legislative power, approval of the NextGeneration EU fund, and the Multiannual Financial Framework are the tools of economic discourse, yet they do not appeal to the shared values nor the contribution to global 
public welfare. European legitimacy is limited to its partners and does not place emphasis on relations with third-party countries. Public diplomacy of the vaccine is a transactional relationship, not a result of political leadership. Relations with the United Kingdom, pending the exit agreements, are irrelevant.

The second dimension of European legitimacy is regulatory power. The vaccine guarantees legislative and negotiating power of the European Union insofar as it establishes mechanisms of access and production for 27 countries. The contracts with pharmaceutical companies are based on the principle of solidarity of the European project in such a way that health is not commercialised, but instead is a right. Consequently, vaccines are acquired from diverse sources along with technology to cover the needs of the different risk groups. The European narrative is not focused solely on access, but on distribution as well. Here is where the distinction between the European model and the others lies: medical safety (an attribute of reliability) and the principle of equity (equal access to medicine). European legitimacy is built on the public health system, constructed through a labyrinthine network that enables massive, effective distribution.

This set of counter-pandemic measures hinges on economic initiatives. The economy confers legitimacy and continuity to the European project, which is the third level of strategic narratives. The EU's political legitimacy is validated by stable public policies. On the other hand, this approach has not been able to counteract the nationalist discourse of the EU countries themselves for the same reason. Not even the emergence of a new systemic rival has succeeded in unifying the discourse of identity, collective action, and enhanced cooperation. Thus, the European agenda has not managed to unify the European public sphere and the external message has been insufficient. After approval of the Next-Generation EU Funds, chaos has returned to the European narrative. The inability to carry out distribution, delivery delays, and the loophole in the AstraZeneca contract have weakened the normative or referential power narrative.

\section{Russia: resurgence through scientific leadership}

Initially, the Russian Federation underestimated the impact of the COVID-19 pandemic and gave prominence to professional experts because it had fewer cases of infection than France or the UK. However, the rapid rise in the number of infections has transformed President Putin's policy measures. The Russian president has become aware of the fact that the crisis is a good opportunity to deploy the scientific narrative and to strengthen Russia's position in the world order. Russia's legitimacy narrative is built on the foundation of efficiency and scientific leadership. Without the financial muscle to support neither solidarity measures nor shipments of medical products and supplies, Russia has led the race for the vaccine. Despite the scientific community's doubts and initial misgivings, the vaccine works (Groopman 2021).

Science is a tool to be used for making an impact on the international agenda. Moreover, one of the instrumental purposes of scientific advance is to resolve worldwide public health problems, which places the salience of Russian public diplomacy in a competitive space. Regarding legitimacy, Putin's statements have stressed the idea that Russia is making a net contribution to finding a resolution to the crisis, and have also served to highlight the efficiency of the country's public health system, medical research, and its willingness to provide international aid. Furthermore, endorsement by The Lancet (Jones and Roy 2021) is essential in structuring the message and positioning the vaccine among the benchmarks of global health quality.

Analysis of the scientific approach reflects the agility of Russian science with the production of the Sputnik V vaccine, a name well-known in space exploration. The choice of the name relates to its association with the 1957 satellite launch, a political event that led to international recognition of Soviet technological supremacy. The zeal for a glorious past is one of the characteristics of pandemic nationalism, which implies instrumental advances in the scientific community. The Russian website publishes up-to-date information in eight languages, high-resolution images, and explanatory videos. The vaccine serves the purpose of public diplomacy with a message of strategic sovereignty capable of providing state-of-the-art advances in biomedicine.

Sputnik V relies on funding from the state-sponsored Russian Direct Investment Fund. This sovereign wealth fund has assets of ten billion dollars, with its priority being the consolidation of a Russian vaccine capable of competing on the world market. It was developed by the state-owned Gamaleya Institute, whose organisation, funding and governance are inaccessible. Since July of 2020, Russian sources have praised the scientific qualities and safety of the vaccine. Alexander Gintsburg, director of the virology research centre, stated that the results have been a 'monumental achievement' and a 'great success in the battle against the worldwide COVID-19 pandemic' (Mancini and Seddon 2021).

This message of strategic autonomy in the field of science and biotechnology places Russia on a par with other vaccine manufacturers, namely the European Union, the United Kingdom, and China. Presidential leadership has been displayed in the inoculation of Putin, the image of which has sent the message that the 'vaccine is safe', although he has still not fulfilled his promise of public vaccination and has created a work area, or a type of bubble, with restrictions. Production of the Russian vaccine required private investment in order to reach two million doses by the end of 2020, and up to an expected thirty million by the summer of 2021 . 
Science has a significant economic dimension. The vaccine is a guarantee of economic recovery at home and abroad (Osborn and Nikolskaya 2020). It has already had an effect on Putin's popularity, according to data from the Levada Centre, an independent organisation for polling and sociological research. Together with domestic recovery, an additional 500 million doses at an approximate cost of ten dollars per unit have been exported to Saudi Arabia, the United Arab Emirates, Indonesia, the Philippines, Brazil, Mexico and India, as well as to states of the post-soviet region, which represents an enormous amount of income for the badly damaged Russian economy. India has acquired 200 million doses; South Korea, 150 million; and Egypt, 25 million. Special relations with Argentina, Mexico and Venezuela are the result of a personal connection with the presidents of those countries. The acquisition of 25 million doses have ground to a halt due to the nonexistence of additional tests for the demographic group of seniors over 60 years of age, expectant mothers, and those with chronic illnesses. Without international success, scientific prestige declines. For that reason, the narrative has been strengthened by highlighting the quality of the vaccine with messages such as, 'more effective than western rivals', 'it outperforms', 'above 95\%', and 'the effectiveness rate is expected to be even higher based on data collected three weeks after the second immunisation, when the body's strongest and most stable response is achieved' (Seddon and Mancini 2020).

With regard to Russia's position, the impact of the vaccine on relations with the European Union is of interest. Economic instability and the slow pace of European medical bureaucracy have been used to discredit the current model and to regain a prominent position in Eastern European countries. The vaccine has only found one buyer, the country of Hungary, which has ruptured European unity in the EU's bid to be a single market. This is a powerful message in the Russian narrative, which is searching for potential alliances in European territory. Scientific support has discredited the European Commission itself, whose disdain for Russian rigour has been disputed. At the East Stracom, more than 50 pieces denouncing these practices can be found.

These actions have constructed the legitimacy narrative. According to Theresa Fallon of the Centre for Russia-Europe-Asia Studies, a think tank based in Brussels, 'This is a card that Vladimir Putin can play to move from the narrative held by some in the international community that Russia is a pariah state after the annexation of Crimea, to a more positive narrative of a vaccine provider and "liberator" of people from the pandemic' (Chassany 2021). Even so, Ukraine has ruled out the purchase of Sputnik V. The nearly inaudible echo in the Balkans is surprising, where the provision of medical assistance has not achieved the same success as the Chinese products.
Sabotaje de la OMS y Microsoft a la vacuna rusa Sputnik $v$

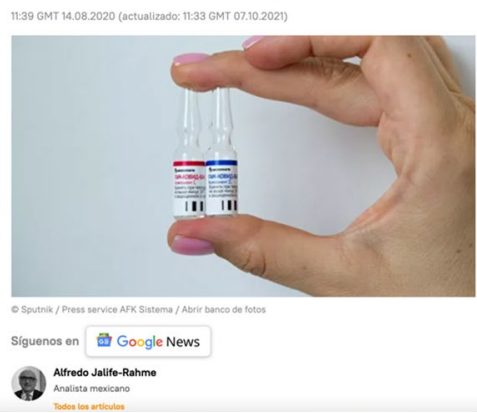

Fig. 2 Sputnik media spreading misinformation about the Russian vaccine in Latin America

In Latin America, the Russian vaccine is dominant with recurring substantiation by political leaders. In Mexico, 24 million doses of Sputnik were purchased even before approval by the relevant regulatory body. In Argentina, health authorities approved the vaccine, and President Alberto Fernandez himself has received his dose. Nicaragua has expressed interest in becoming the factory and distribution hub of the vaccine for Central America. Venezuela has acquired the formula for local production in accordance with the Russian patent. Finally, in Bolivia, the Russian vaccine is the benchmark for the public health system. Sputnik and RT deployed extraordinal activity to support Russian vaccines against Western powers, including the WHO or Microsoft (Fig. 2).

In summary, the Russian vaccine represents an exercise in public diplomacy in response to the economic dimension (investment and exports), national identify (domestic prestige), and spheres of influence (privileged relations in its geographic environment).

\section{Conclusions}

COVID-19 has created a new narrative category for countries with a view to the future by impelling them to promote their own values and not necessarily those that form part of mainstream hegemonic globalisation. The vaccine symbolises worldwide public health policy, which offers prestige and reputation to reinforce political and economic projects.

In the cases study, the political response has contributed to the nationalist narrative at all levels. The phenomenon of a foreign origin as the carrier of the virus is a recurrent theme. The rejection of immigrants coming from Hubei within the Chinese territory itself, the flare up of racism in China against the African population, the dispute between Madrid and Barcelona, confrontation between the North 
and South of Italy, nationalist discourse between the two regions in Belgium, fear of the Swedish decision regarding 'herd immunity', and other cases are a reminder of the ease with which nationalism can be ignited in emergency situations. In the European Union, the virus led to nationalist decisions between March and April, which have since declined in the face of European bureaucracy. The lack of capability of individual nations has contributed to the escalation of the discussion in the European Council. However, Europe has organised mass repatriations of nationals due to the closure of borders for fear of the virus. Restrictions on movement do not apply to nationals, but this is due to matters related to passports rather than medical appropriateness. The nationalism of repatriation, with or without sanitary controls at airports, has had a negative effect on controlling the infection. A new outbreak in the United Kingdom in the third quarter of 2020 represented the perfect storm for the study of pandemic nationalism: closures of borders and air connections, exhaustive control in the road transport of merchandise, express repatriations with the Christmas holidays approaching at the time, lack of a coordinated response by the European Union, acceleration of the Brexit negotiations, comments against minorities, and all manner of nationalist declarations regarding the import of the new strain. These examples constitute a kind of pandemic nationalism, which serves political interests.

Such pandemic nationalism determines the narrative of public diplomacy using counter-pandemic measures and vaccines to sustain a charismatic message. The narratives express the 'universal' aspect of their vaccine, yet these countries limit its distribution and set prices subject to the acquisition of other complementary measures (such as political relations and investment). The available vaccines compete as much for their scientific quality as for the externalities that their acquisition generates. Their procurement is exclusive compared to procedures for other public purchases. Thus, international developers of pharmaceutical products cannot collaborate, which undermines the value of science as a vehicle for public diplomacy. The science of the vaccine is national and is a response to the priorities of foreign policy, not to the doctrine of global public welfare. In summary, pandemic nationalism has converted anti-COVID-19 initiatives into an instrument for positioning a political undertaking on the international stage by fostering specific values related to identity and legitimacy.

In summary, the cases examined in this paper will help to expand the research related to legitimacy narratives in the new domains of globalisation. The analysis herein advances a theoretical construction and offers a case study that updates previous work, providing the research corpus with new paths of investigation, such as deinstitutionalisation of public diplomacy, the primacy of the executive branch with the consequence of the president over the state, and the use of medical science as arguments for power and prestige.

Funding Funding was provided by Ministerio de Ciencia, Innovación y Universidades (Grant No. RTI2018-096733-B-I00).

\section{References}

Alkemy Lab. 2020. Data intelligence comunicazione Cinese in Italia. https://formiche.net/files/2017/07/Social-Data-IntelligenceComunicazione-cinese-ricerca-per-Formiche-1.pdf.

Antoniades, Andreas, A. Miskimmon, and B. O'Loughlin. 2010. Great power politics and strategic narratives. In CGPE Working Paper Brighton: Centre for Global Political Economy, University of Sussex. http://www.sussex.ac.uk/cgpe/documents/cgpe wp07_antoniades_miskimmon_oloughlin.pdf.

Associated Press. 2020. China's companies emerge as global donors in virus pandemic. Associated Press, June, 9. https://www. voanews.com/COVID-19-pandemic/chinas-companies-emergeglobal-donors-virus-pandemic.

Bakalov, Ivan. 2019. Whiter soft power divisions, milestones, and prospects of a research program in the making. Journal of Political Power 12: 129-151.

BBC. 2020. Trump says coronavirus 'attack' is worse than Pearl Habor. May, 7. https://www.bbc.com/news/world-us-canada52568405 .

Bially, M.J. 2005. Why 'soft power' isn't so soft: Representational force and the sociolinguistic construction of attraction in world politics. Millennium Journal of International Studies 33 (3): 583612. https://doi.org/10.1177/03058298050330031601.

Bjola, C., J. Cassidy, and I. Manor. 2019. Public diplomacy in the digital age. In Debating public diplomacy, ed. J. Melissen and J. Wang, 83-101. Leiden: Brill.

Bødker, H., and C. Anderson. 2019. Populist time: Mediating immediacy and delay in liberal democracy. International Journal of Communication 13: 5948-5966.

Borrell, Josep. 2020. EU HRVP Josep Borrell: The Coronavirus pandemic and the new world it is creating. https://eeas.europa.eu/ delegations/china/76401/eu-hrvp-josep-borrell-coronavirus-pande mic-and-new-world-it-creating_en

Bown, C. 2020. How Trump's export curbs on semiconductors and equipment hurt the US technology sector, Peterson Institute for International Economics, https://www.piie.com/blogs/trade-andinvestment-policy-watch/how-trumps-export-curbs-semiconduc tors-and-equipment-hurt-us

Brands, H. 2017. U.S. grand strategy in an age of nationalism: Fortress America and its alternatives. The Washington Quarterly 40 (1): 73-94. https://doi.org/10.1080/0163660X.2017.1302740.

Brandt, J. and B. Schafer. 2020. How China's wolf warrior diplomats use and abuse Twitter. Brookings Institution. https://www.brook ings.edu/techstream/how-chinas-wolf-warrior-diplomats-use-andabuse-twitter/

Cha, T. 2016. The return of Jacksonianism: The international implications of the Trump phenomenon. The Washington Quarterly 39 (4): 83-97. https://doi.org/10.1080/0163660X.2016.1261562.

Chadwick, A. 2013. The hybrid media system: Politics and power. New York: Oxford University Press.

Chassany, Anne-Sylvaine. 2021. The west should pay attention to Russia and China's vaccine diplomacy. Financial Times https://www. ft.com/content/c20b92f0-d670-47ea-a217-add1d6ef2fbd 
Chen, W., ed. 2017. The Beijing consensus? How China has changed western ideas of law and economic development. New York: Cambridge University Press.

Chernobrov, D., and E.L. Briant. 2020. Competing propagandas: How the United States and Russia represent mutual propaganda activities. Politics. https://doi.org/10.1177/0263395720966171.

Chow-Bing, Ngeow. 2020. COVID-19 speeds up China's Health Silk Road. East Asia Forum. https://www.eastasiaforum.org/2020/05/ 26/COVID-19-speeds-up-chinas-health-silk-road/.

Clarke, M., and A. Ricketts. 2017. US grand strategy and national security: The dilemmas of primacy, decline and denial. Australian Journal of International Affairs 71 (5): 479-498. https://doi.org/ 10.1080/10357718.2017.1342760

Cooper, A.F. 2019. Adapting public diplomacy to the populist challenge. The Hague Journal of Diplomacy 14 (1-2): 36-50. https:// doi.org/10.1163/1871191X-14101011.

Coratella, T. 2020. The dangers of crisis diplomacy: Italy, China, and Russia. European Council on Foreign Relations. https://www.ecfr. eu/article/commentary_the_dangers_of_crisis_diplomacy_italy_ china_and_russia

Crilley, R. 2018. International relations in the age of post-truth politics. International Affairs 94 (2): 147-425. https://doi.org/10.1093/ia/ iiy038.

Cull, Nicholas J. 2021. From soft power to reputational security: Rethinking public diplomacy and cultural diplomacy for a dangerous age. Place Brand Public Diplomacy. https://doi.org/10. 1057/s41254-021-00236-0v.

Davies, Sara E., and Clare Wenham. 2020. Why the COVID-19 response needs International Relations. International Affairs 96 (5): 1227-1251.

Duke Global Health Innovation Center. 2020. Mapping COVID-19 Vaccines Pre-purchases across the globe. https://launchandscalef aster.org/COVID-19. Accessed 14 Dec 2021.

European Commission. 2019. EU-China. A strategic outlook. https:// ec.europa.eu/commission/sites/beta-political/files/communicat ion-eu-china-a-strategic-outlook.pdf

Evenett, Simon J., and Johannes Fritz. 2020. Collateral damage. Cross-border fallout from pandemic policy overdrive. Washington: CEPR Press.

Ferrara, Emilio, Stefano Cresci, and Luca Luceri. 2020. Misinformation, manipulation, and abuse of social media in the era of COVID-19. Journal of Computational Social Science 3: 271-277.

Frankopan, P. 2018. The new silk roads. The present and the future of the world. London: Bloomsbury Publishing.

Gereff, Gary. 2020. What does the COVID-19 pandemic teach us about global value chains? The case of medical supplies. Journal of International Business Policy 3 (2020): 287-301.

Groopman, Jerome. 2021. The politics of stopping pandemics. The New Yorker, March, 29.

Hawley, J. 2020. The WTO should be abolished. New York: The New York Times.

Henley, Jon and Eleanor Ainge Roy. 2020. Are female leaders more successful at managing the coronavirus crisis? Guardian. https:// www.theguardian.com/world/2020/apr/25/why-do-femaleleaders-seem-to-be-more-successful-at-managing-the-coron avirus-crisis

Hayden, C. 2012. Social media at state: Power, practice, and conceptual limits for US Public Diplomacy. Global Media Journal-American Edition 11 (21): 1-21. https://doi.org/10.1177/0002716207 311863.

Hotez, Peter J. 2021. Immunizations and vaccines: A decade of successes and reversals, and a call for vaccine diplomacy. International Health 11 (5): 331-333.

Huang, Z.A. 2021. "Wolf Warrior" and China's digital public diplomacy during the COVID-19 crisis. Place Brand Public Diplomacy. https://doi.org/10.1057/s41254-021-00241-3.
Hussain, H.H., and P.N. Howard. 2013. What best explains successful protest cascades? ICTs and the fuzzy causes of the Arab Spring. International Studies Review 15 (1): 48-66.

Jones, I., and I. Roy. 2021. Sputnik V COVID-19 vaccine candidate appears safe and effective. The Lancet. https://doi.org/10.1016/ S0140-6736(21)00191-4.

Kahl, Colin, and Wright, Thomas. 2021. Aftershocks pandemic politics and the end of the old international order. MacMillan.

Katz, E., and D. Dayan. 2018. L'esprit de l'escalier: 25 years of insight. Media, Culture and Society. 40 (1): 143-152.

Kirk, Jessica, and Matt McDonald. 2021. The politics of exceptionalism: Securitization and COVID-19. Global Studies Quarterly 1 (3): 1-12. https://doi.org/10.1093/isagsq/ksab024.

Kornprobst, Markus, and Stephanie Strobl. 2021. Global health: An order struggling to keep up with globalization. International Affairs 97 (5): 1541-1558.

Kynge, J. and H. Lockett, H. 2020. From cover-up to global donor: China's soft power play. Financial Times https://www.ft.com/ content/efdec278-6d01-11ea-9bca-bf503995cd6f.

Lau, Stuart and Catherine Wong. 2020. Germany pushes China for answers to coronavirus origin. South China Morning Post, April, 21. https://www.scmp.com/news/china/diplomacy/article/30809 18/germany-pushes-china-answers-coronavirus-origin-adding.

Lee, Seown Ting. 2021. Vaccine diplomacy: Nation branding and China's COVID-19 soft power play. Place Branding and Public Diplomacy. https://doi.org/10.1057/s41254-021-00224-4.

Li, Cheng, and Ryan McElveen. 2020. Mask diplomacy: How coronavirus upended generations of China-Japan antagonism. Brookings. https://www.brookings.edu/blog/order-from-chaos/ 2020/03/09/mask-diplomacy-how-coronavirus-upended-gener ations-of-china-japan-antagonism/.

Lun Tian, Yew. 2020. In "People's War" on coronavirus, Chinese propaganda faces pushback, Reuters. https://www.reuters. com/article/us-health-coronavirus-china-propaganda-a-idUSK BN2100NA.

Malacalza, Bernabé, and Débora. Fagaburu. 2021. ¿Empatía o cálculo? Un Análisis Crítico De La Geopolítica De Las Vacunas En América Latina. Foro Internacional, LXII 247: 5-45.

Mancini, D.P. and M. Seddon. 2021. Russia's Sputnik vaccine shows 91.6\% efficacy in clinical trials. Financial Times. https://www.ft. com/content/1180d24e-eeaf-4316-a507-3108bba52c28

Manor, Ilan, and James Pamment. 2021. From Gagarin to Sputnik: The role of nostalgia in Russian public diplomacy, Place Branding and Public Diplomacy.

Mason. 2020. White House slams WHO over criticism of push for COVID-19 vaccine. Reuters. https://www.reuters.com/article/ health-coronavirus-usa-who/update-2-white-house-slams-whoover-criticism-of-push-for-COVID-19-vaccine-idUKL1N2FY 1SW? edition-redirect $=$ in.

National Health Commission of the People's Republic of China. 2017. Beijing Communique of The Belt and Road Health Cooperation and Health Silk Road. http://en.nhc.gov.cn/2017-08/18/c_72257. htm.

Nye, J.S. 2021. Soft power: The evolution of a concept. Journal of Political Power. https://doi.org/10.1080/2158379X.2021.18795 72.

Ociepka, B. 2018. Public diplomacy as political communication: Lessons from case studies. European Journal of Communication 33 (3): 290-303. https://doi.org/10.1177/0267323118763909.

Osborn, A and P. Nikolskaya. 2020. Russia, eyeing foreign markets, says Sputnik COVID-19 vaccine to cost under \$20. Reuters. https://www.reuters.com/article/us-health-coronavirus-russiavaccine-idUSKBN28415J.

Peel, Michael. 2020. China hits back at EU disinformation claims. Financial Times. https://www.ft.com/content/6cbb9b22-873546ba-88a7-cb3e04cad6db. 
Peel, Michael, Mehreen Khan, Dombey Dombey, and Laura Pitel. 2020. Countries reject China pandemic product batches. https:// www.ft.com/content/f3435779-a706-45c7-a7e2-43efbdd7777b.

Price, M. 2003. Public diplomacy and the transformation of international broadcasting. Cardoza Arts and Entertainment Law Journal 21 (1): 51-85.

Price, M. 2015. Free expression, globalism and the new strategic communication. New York, NY: Cambridge University Press.

Ragin, C.C. 2000. Fuzzy-set social science. Chicago: University of Chicago Press.

Ramo, J.C. 2004. The Beijing consensus. London: Foreign Policy Centre.

Ronfeldt, David, and John Arquilla. 2020. Whose story wins. Rise of the noosphere, noopolitik, and information-age statecraft. Santa Monica: Rand Corporation.

Roselle, L. 2010. Strategic Narratives of War: Fear of Entrapment and Abandonment During Protracted Conflict. SGIR: Stockholm. http://stockholm.sgir.eu/uploads/Strategic\%20Narratives\%20of\% 20War.pdf.

Roselle, L., and S. Spray. 2012. Research and writing in international relations. New York: Pearson.

Roselle, L., A. Miskimmon, and B. O’Loughlin. 2014. Strategic narrative: A new means to understand soft power. Media, War and Conflict 7 (1): 70-84. https://doi.org/10.1177/1750635213516696.

Sardarizadeh, Shayan and Olga Robinson. 2020. Coronavirus: US and China trade conspiracy theories. BBC Monitoring. https://www. bbc.com/news/world-52224331

Seoane, Francisco. 2013. Political communication in Europe. The cultural and structural limits of the European Public Sphere. London: Palgrave Macmillan.

Seddon, M. and D.P. Mancini. 2020. Russia says Sputnik virus vaccine more effective than western rivals. Financial Times, https://www. ft.com/content/83e7b65d-89cb-48f8-a42c-0d528236a122

Sharp, Paul, Jan Melissen, Qingmin Zhang, and Zhang. 2021. China's Global Diplomacy. The Hague Journal of Diplomacy 16: 195-202.

Sheperd, Christian, Stephanie Findlay, and Stefania Palma. 2020. China's Covid-10 vaccine diplomacy steals a march on US. Financial Times, https://www.ft.com/content/ce9a4c98-49b5-4c24-9ff2ed1c6a3f3412

Shively, W.P. 2013. The Craft of Political Science Research. New York: Pearson.

Simic, J. 2020. Serbia turns to China due to 'lack of EU solidarity' on coronavirus. Euractiv, March, 18. https://www.euractiv.com/ section/china/news/serbia-turns-to-china-due-to-lack-of-eu-solid arity-on-coronavirus/

Simoes and Liu. 2020. Brazil's Bolsonaro claims victory as Sinovac COVID-19 trial halted. https://www.reuters.com/article/uk-healthcoronavirus-brazil-sinovac-idINKBN27Q1BO

Smith, David. 2020. Trump talks himself up as wartime president to lead America through a crisis. The Guardian. https://www.thegu ardian.com/us-news/2020/mar/22/trump-coronavirus-electionnovember- 2020

Spinetto, J.P. and Adghirni. 2020. China Gives \$1 Billion Loan for Latin America Vaccine Access. Bloomberg. https://www.bloom berg.com/news/articles/2020-07-23/china-to-give-1-billion-loanfor-latin-america-vaccine-access

State Council. 2020. Fighting COVID-19: China in Action. http://engli sh.scio.gov.cn/whitepapers/2020-06/07/content_76135269.htm

Stott, M. 2020. China cleans up in Latin America as US flounders over coronavirus. Financial Times. https://www.ft.com/content/741e7 2ed-e1db-4609-b389-969318f170e8

Suarez, K. 2020. China offers \$1 billion loan to Latin America and the Caribbean for access to its COVID-19 vaccine. CNN, July, 24. https://edition.cnn.com/2020/07/23/americas/china-billion-vacci ne-latin-america-coronavirus-intl/index.html

The Lancet. 2020. The COVID-19 infodemic. 17, July, https://doi.org/ 10.1016/S1473-3099(20)30565-X

The Lancet. 2021. Lancet Glob Health. 9: e1017-21. Published Online March 26, 2021. https://doi.org/10.1016/S2214-109X(21)00140-6

Viala-Gaudefroy, Jérôme and Dana Lindaman. 2020. "Donald Trump's Chinese Virus: the politics of naming". The Conversation, April 23. Retrieved from https://theconversation.com/donald-trumpschinese-virus-the-politics-of-naming-136796

Winkler, Stephanie. 2020. Conceptual politics in practice: how soft power changed the word, Stockholm Studies in International Relations, 3.

Xie, Echo. 2020. Jack Ma donates masks, medical supplies to help coronavirus fight in Asia and Latin America, South China Morning Post, March, 22. Retrieved from: https://www.scmp.com/news/ china/diplomacy/article/3076319/jack-ma-donates-18-millionmasks-medical-supplies-help

Zhang, Zoey. 2020. What is China's Dual Circulation Strategy?, American Chamber Insight Magazine, Retrieved from https:// www.amcham-shanghai.org/en/article/what-chinas-dual-circu lation-strategy

Publisher's Note Springer Nature remains neutral with regard to jurisdictional claims in published maps and institutional affiliations.

Juan Luis Manfredi Sánchez is Prince of Asturias Distinguished Professor at Georgetown University. He examines how deglobalization affects diplomacy, political leadership and international communication. He is also Associate Professor at the University of CastillaLa Mancha, where he teaches Journalism and International Relations. Currently, his research group is carrying out comparisons of urban diplomacy in Europe and Latin America (Grant reference number: RTI2018-096,733-B-I00). 